\title{
Anastrepha aczeli Blanchard and Anastrepha similis Greene (Diptera: Tephritidae) in Minas Gerais, Brazil
}

\author{
Anastrepha aczeli Blanchard e Anastrepha similis Greene \\ (Diptera: Tephritidae) em Minas Gerais, Brasil
}

\author{
Pedro Augusto Silva Duarte ${ }^{\mathrm{I}}$ Flávio Roberto Mello Garcia ${ }^{\text {II }}$ \\ Vanessa AndalóiII
}

\section{ABSTRACT}

The occurrence of Anastrepha aczeli Blanchard and Anastrepha similis Greene (Diptera: Tephritidae) is recorded in the state of Minas Gerais, Brazil. Specimens of A. aczeli were found in traps placed in orchards of acerola, Malpighia emarginata DC (Malpighiaceae), and citrus, Citrus sinensis (L.) Osbeck (Rutaceae), and A. similis was obtained in traps placed in citrus orchards located in the county of Bambui, MG, Brazil.

Key words: citrus, fruit fly, orchards, pest, tephritid.

\section{RESUMO}

As ocorrências de Anastrepha aczeli Blanchard e Anastrepha similis Greene (Diptera: Tephritidae) são registradas pela primeira vez no estado de Minas Gerais, Brasil. Os espécimes de A. aczeli foram encontrados em armadilhas montadas em pomares de acerola, Malpighia emarginata DC (Malpighiaceae), e citros, Citrus sinensis (L.) Osbeck (Rutaceae), e os de A. similis obtidos em armadilhas montadas em pomares de citros, em pomares instalados no município de Bambuí, MG, Brasil.

Palavras-chave: citros, mosca-das-frutas, fruticultura, praga, tefritideo.

The fruit fly Anastrepha similis Greene was first observed in Panama, city of Cabima, through collections in traps (STONE, 1942; THOMPSON, 1998). Anastrepha aczeli Blanchard was first observed in Argentina, province of Tucuman (THOMPSON, 1998; ZUCCHI, 2008). Anastrepha similis and $\boldsymbol{A}$. aczeli have records of occurrence in the states of Rio Grande do Sul (GARCIA \&
CORSEUIL, 2004) and Santa Catarina (GARCIA et al., 2002, 2003), southern Brazil, and their hosts are still unknown (ZUCCHI, 2008).

Thus, the aim of the study was to conduct a survey of fruit flies in orchards located in the region of Bambuí, MG, Brazil, in order to verify the occurrence of these insects.

Collection of fruit flies was performed in four orchards located in the municipality of Bambuí, MG, (2002' 22.73"' S; 4600' 29.39”' W; 725.9m). The climate type is high-altitude tropical, classified according to Köppen as Cwa, with dry winter and rainy summer, annual mean minimum temperature of $22.0^{\circ} \mathrm{C}$ and maximum of $28.4^{\circ} \mathrm{C}$, and annual mean rainfall of $1,272 \mathrm{~mm}$. Twenty traps were placed in the citrus orchard, 10 traps in the acerola orchard, 10 traps in the guava area and 10 traps in the fig area, with a total area of $2.5 \mathrm{ha}$. The specimens were obtained from collections made through the use of fly traps, made out of a 1.5L PET bottle. Inside the bottle sugarcane molasses $20 \%$ was added, at approximately $300 \mathrm{~mL} /$ trap. The traps were placed in the trees, at a height of approximately $1.60 \mathrm{~m}$ above the ground, remaining in the field for seven days, and the molasses were periodically replaced. The surveys were conducted from November 2011 to August 2012.

In these surveys two females of $\boldsymbol{A}$. aczeli were collected in traps placed in citrus, and two females of $\boldsymbol{A}$. similis, one in a citrus orchard and the other in an acerola orchard.

IInstituto Federal de Educação, Ciência e Tecnologia de Minas Gerais, Bambuí, MG, Brasil.

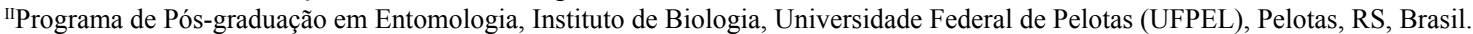

IIInstituto de Ciências Agrárias, Universidade Federal de Uberlândia (UFU), 38500-000, Monte Carmelo, MG, Brasil. E-mail: vanessaandalo@iciag.ufu.br. "Corresponding author. 
According to GARCIA et al. (2003) both species were also found in traps placed in citrus orchards in a survey performed in Santa Catarina, region of Chapecó, which the climate type according to Köppen is classified as Cfa and annual mean rainfall varies between $1500 \mathrm{~mm}$ e $2000 \mathrm{~mm}$. The climate characteristics differ of the climate in Bambuí region.

ALVARENGA et al. (2009, 2010) conducted surveys of fruit flies in orchards located in the northern region of Minas Gerais. In these studies the prevalence of Anastrepha fraterculus (Wiedemann) and Anastrepha obliqua (Macquart) was observed, but no specimens of $\boldsymbol{A}$. similis and A. aczeli were found. SOUZA et al. (2012) also performed a survey in the northern State of Minas Gerais and found five species of Anastrepha, including $A$. zenildae, $A$. obliqua, $A$. sororcula, $A$. fraterculus and $A$. turpiniae in Viçosa, Minas Gerais, Brazil, a survey was carried out of species of fruit flies associated with citrus orchards, and the only species found was $\boldsymbol{A}$. fraterculus (MACHADO et al., 2012).

The insects obtained in the present survey were identified through the STEYSKAL (1977) and ZUCCHI (2000) keys. One characteristic that differentiates the species $\boldsymbol{A}$. similis from the others is the aculeus measuring $2.8 \mathrm{~mm}$ to $2.9 \mathrm{~mm}$ (NORA et al., 2000) and $\boldsymbol{A}$. aczeli presented as a differentiating feature aculeus approximately $2 \mathrm{~mm}$ long (KOVALESKI et al., 2000).

The list of species of fruit flies of the genus Anastrepha present in Minas Gerais State, has currently 29 species (ZUCCHI, 2008), so the present study adds the species $\boldsymbol{A}$. aczeli and $\boldsymbol{A}$. similis to the list, now presenting richness of 31 species.

Considering that Brazil is one of the world's main producers of fruit for domestic consumption and for export, it is particularly important to record insects associated with these crops, monitoring the planting areas constantly to verify the spatial and temporal distribution, to prevent economic damage.

\section{ACKNOWLEDGEMENTS}

The authors thank the Conselho Nacional de Desenvolvimento Científico e Tecnológico $(\mathrm{CNPq})$ and the Fundação de Amparo à Pesquisa do Estado de Minas Gerais (FAPEMIG) for financial support

\section{REFERENCES}

ALVARENGA, C.D. et al. Moscas-das-frutas (Diptera: Tephritidae) e seus parasitoides em plantas hospedeiras de três municípios do norte do estado de Minas Gerais. Arquivos do
Instituto Biológico, v.76, n.2, p.195-204, 2009. Available from: $<$ http://www.biologico.sp.gov.br/docs/arq/v76_2/alvarenga. pdf>. Accessed: Jul. 03, 2014.

ALVARENGA, C.D. et al. Moscas-das-frutas (Diptera: Tephritidae) em pomares da área urbana no norte de Minas Gerais. Revista Caatinga, v.23, p.25-31, 2010. Available from: $<$ http://periodicos.ufersa.edu.br/revistas/index.php/sistema/article/ view/1738/4565>. Accessed: Jul. 03, 2014.

GARCIA, F.R.M. et al. Lista documentada das moscas-das-frutas (Diptera: Tephritidae) de Santa Catarina, Brasil. Biociências, v.10, p.139-148, 2002.

GARCIA, F.R.M. et al. Análise faunística de espécies de moscasdas-frutas (Diptera: Tephritidae) na Região Oeste de Santa Catarina. Neotropical Entomology, v.32, n.3, p.421-426. 2003. Available from: <http://www.scielo.br/pdf/ne/v32n3/18754.pdf>. Accessed: Jul. 03, 2014.

GARCIA, F.R.M.; CORSEUIL, E. Lista documentada das moscasdas-frutas (Diptera: Tephritidae) do Rio Grande do Sul, Brasil. Acta Ambiental Catarinense, v.3, p.23-32, 2004.

KOVALESKI, A. et al. Moscas-das-frutas de importância econômica no Brasil: conhecimento básico e aplicado. Ribeirão Preto: Holos, 2000. p.285-290.

MACHADO, D.L.M. et al. Levantamento de moscas-das-frutas e seus parasitoides em citros, no município de Viçosa, Minas Gerais. Revista Ceres, v.59, p.877-880, 2012. Available from: $<$ http://www.ceres.ufv.br/ceres/revistas/V59N006P09711.pdf $>$. Accessed: Jul. 03, 2014.

NORA, I. et al. Santa Catarina. In: MALAVASI, A.; ZUCCHI, R.A. Moscas-das-frutas de importância econômica no Brasil: conhecimento básico e aplicado. Ribeirão Preto: Holos, 2000. p.271-275.

SOUZA, A.R. et al. Hymenopteran parasitoids associated with frugivorous larvae in a Brazilian Caatinga-Cerrado ecotone. Environmental Entomology, v.41, p.233-237, 2012. Available from: <http://www.bioone.org/doi/abs/10.1603/EN11121>. Accessed: Sept. 09, 2014.

STEYSKAL, G.C. Pictorial key to species of the genus Anastrepha (Diptera: Tephritidae). Washington: The Entomological Society of Washington, 1977. 35p.

STONE, A. The fruitflies of the genus Anastrepha. Miscellaneous Publication, 439. Washington: United States Department of Agriculture, 1942. 112p.

THOMPSON, F.C. Fruit fly expert identification system and systematic database of names. Leiden: North American Dipterists' Society, Backhuys Publishers, 1998. 524p.

ZUCCHI, R.A. Taxonomia. In: MALAVASI, A.; ZUCCHI, R.A. Moscas-das-frutas de importância econômica no Brasil: conhecimento básico e aplicado. Ribeirão Preto: Holos, 2000. p.13-24.

ZUCCHI, R.A. Fruit flies in Brazil - Anastrepha species their host plants and parasitoids. 2008. Available from: $<$ http://www. lea.esalq.usp.br/anastrepha>. Online. Accessed: Jul. 03, 2014. 